\title{
Evaluation of the Chagas Disease Control Program in Açucena Municipality, Rio Doce Valley, State of Minas Gerais, Brazil
}

\author{
Adriana dos Santos ${ }^{[1]}$, Rejane Balmant Letro ${ }^{[1]}$, Vitor Antônio Lemos do Bem ${ }^{[1]}$, \\ Bernardino Vaz de Melo Azeredo ${ }^{[2]}$, George Luiz Lins Machado Coelho ${ }^{[3]}$, Liléia Diotaiuti ${ }^{2]}$, \\ Girley Francisco Machado-de-Assis ${ }^{[1]}$ and Marta de Lana ${ }^{[1],[4]}$
}

[1]. Núcleo de Pesquisas em Ciências Biológicas, Universidade Federal de Ouro Preto, Ouro Preto, MG. [2]. Laboratório de Triatomíneos e Epidemiologia da Doença de Chagas, Centro de Pesquisas René Rachou, Fundação Oswaldo Cruz, Belo Horizonte, MG. [3]. Departamento de Ciências Médicas, Escola de Medicina, Universidade Federal de Ouro Preto, Ouro Preto, MG. [4]. Departamento de Análises Clínicas, Escola de Farmácia, Universidade Federal de Ouro Preto, Ouro Preto, MG.

\begin{abstract}
Introduction: Açucena Municipality, Rio Doce Valley, State of Minas Gerais, Brazil temporarily (2001-2005) interrupted epidemiological surveillance for Chagas disease. The objective of this work was to evaluate the Chagas Disease Control Program (CDCP) in Açucena and to offer suggestions for improving local epidemiological surveillance. Methods: This study was conducted in three phases: I) a serological investigation of schoolchildren aged 5 to 15 years using an enzyme-linked immunosorbent assay (ELISA) test performed on blood collected on filter paper followed by ELISA, indirect immunofluorescence (IIF) and indirect hemaglutination (IHA) on venous blood for borderline cases and those in the gray zone of reactivity; II) vector evaluation using the data obtained by local health agents during 2006-2010; and III) examination by ELISA, IIF and IHA of serum samples from the inhabitants of houses where infected Triatoma vitticeps was found and evaluation of their knowledge about Chagas disease. Results: Five individuals had inconclusive results in the ELISA screening but were seronegative for Chagas disease. The triatomine evaluation revealed the presence of three species: Triatoma vitticeps, Panstrongylus megistus and Panstrongylus diasi. Triatoma vitticeps was the most prevalent and widespread, with a higher (67\%) index of Trypanosoma cruzi flagellates and evidence of colonization. Most of the inhabitants of the infested houses recognized triatomines and had basic knowledge about Chagas disease. Conclusions: Although T. vitticeps is not clearly associated with Chagas disease transmission, these results highlight the importance of maintaining CDCP in endemic areas and the need for greater emphasis on epidemiological surveillance, especially in areas with important vectorial changes or that have been modified by human intervention.
\end{abstract}

Keywords: Chagas disease. Serological investigation. Triatomines. Triatoma vitticeps. Epidemiological surveillance. Chagas disease Control Program.

\section{INTRODUCTION}

Chagas disease, or American trypanosomiasis, is a parasitic disease caused by the hemoflagellate protozoan Trypanosoma cruzi, order Kinetoplastida, family Trypanosomatidae. The World Health Organization (WHO) estimates that 10 million people are infected with $T$. cruzi, mainly in Latin American countries where this disease is endemic, although the exact prevalence in other countries is not currently known. Approximately 25 million people throughout the world are living in risk areas, and in 2008, this disease was responsible for more than 10,000 deaths ${ }^{1,2}$.

\footnotetext{
Address to: Drª Marta de Lana. Escola de Farmácia/UFOP. Campos Universitário, Morro do Cruzeiro, 35400-000 Ouro Preto, MG, Brasil.

Phone/Fax: 5531 3559-1680

e-mail: delana@nupeb.ufop.br

Received 21 January 2014

Accepted 31 March 2014
}

Similarly to several other parasitic diseases, American trypanosomiasis is an example of a disease resultant from human interference in the environment. Trypanosoma cruzi originates from wild areas where it circulates between insect vectors and mammals. The triatomine vectors are hematophagous insects of the order Hemiptera, family Reduviidae, subfamily Triatominae $^{3}$. The Chagas Disease Control Program (CDCP) is mainly focused on the interruption of vectorial transmission due to the large number of wild triatomine species with domiciliation potential ${ }^{4,5}$. The CDCP focuses its activities on the identification of triatomine infestations and the spraying of residual insecticides in all infested houses ${ }^{6}$.

In the national serological inquiry of 1978-1980, the rate of human T. cruzi infection in the rural areas of Açucena was 7.98\% ${ }^{7}$. In the entomological evaluation conducted by the Ministry of Health in 1982, three vector species were predominantly detected: 1) Triatoma sordida with $57.5 \%$ prevalence, $1.2 \%$ positivity for T. cruzi and present in $10.7 \%$ of intradomiciliary captures; 2) Panstrongylus megistus with 27\% prevalence, $1.9 \%$ positivity and present in $24.3 \%$ of intradomiciliary 
captures; and 3) T. infestans with 14\% prevalence, $14.1 \%$ positivity and present in $75.5 \%$ of intradomiciliary captures. After the maintenance of triatomine control for approximately 30 years, the data obtained in 2003 [(Secretary of Health of Minas Gerais State, Regional Health Management (RHM) of Coronel Fabriciano] revealed that $T$. vitticeps was the most captured triatomine species by the residents of Açucena and that $T$. infestans was absent.

In 2000, the responsibility for health-related activities, including vector control, was transferred to the municipalities ${ }^{8}$. Consequently, there were considerable failures in the CDCP because the municipalities were not prepared to assume such responsibilities, and the program resumed its activities in 2005. Taking into account the new situation, the epidemiological changes and the decentralization of control activities, the goal of the present work was to evaluate Chagas disease data in the municipality where the CDCP was introduced in the 1980s and to offer suggestions and information for the improvement of local epidemiological surveillance (ES).

\section{METHODS}

\section{Study area}

Açucena Municipality (Latitude-19.0569-Longitude: -42.5442) is situated in eastern State of Minas Gerais (MG), Rio Doce Valley, $285 \mathrm{~km}$ from Belo Horizonte, the capital of the state (Figure 1). The first systematized vector control interventions in Açucena began during the 1980s and culminated in the installation of ES in 1995/1996. However, its action was limited, with only sporadic visits to domiciles at risk of triatomines infestation or where the presence of the vectors was previously verified or demonstrated. In parallel, it was also observed that the posts of triatomines information (PITs) installed were inactive.

The total population of Açucena is 10,276 inhabitants, and $53.4 \%$ (5,471 inhabitants) live in rural areas (Instituto Brasileiro de Geografia e Estatística -(IBGE), 2010). This municipality has 18 schools, two in the urban area and 16 in the rural area. Of the 2,363 students that were enrolled in these schools in 2008, 1,971 were aged between five and fifteen years and selected for this study.

\section{Serological testing}

For all blood collections, the parents or person responsible for each student received instructions and signed the Instructed and Free Terms of Consent.

Three parameters were used for sample calculation: I) the proportion of individuals infected with T. cruzi in the age group studied in the national investigation of Chagas disease between 1975 and $1980^{\circ}$; II) an acceptable error of 5\%; and III) the number of schoolchildren in the rural zone of the municipality. In the absence of data related to the first parameter, a proportion of $41-50 \%$ of the total schoolchildren was used. The sample size was increased to $50 \%$ for greater reliability and was higher than that recommended for the period by the Health Ministry ${ }^{9}$. The number of children by age group and by school was calculated to estimate who should be examined. Children were stratified

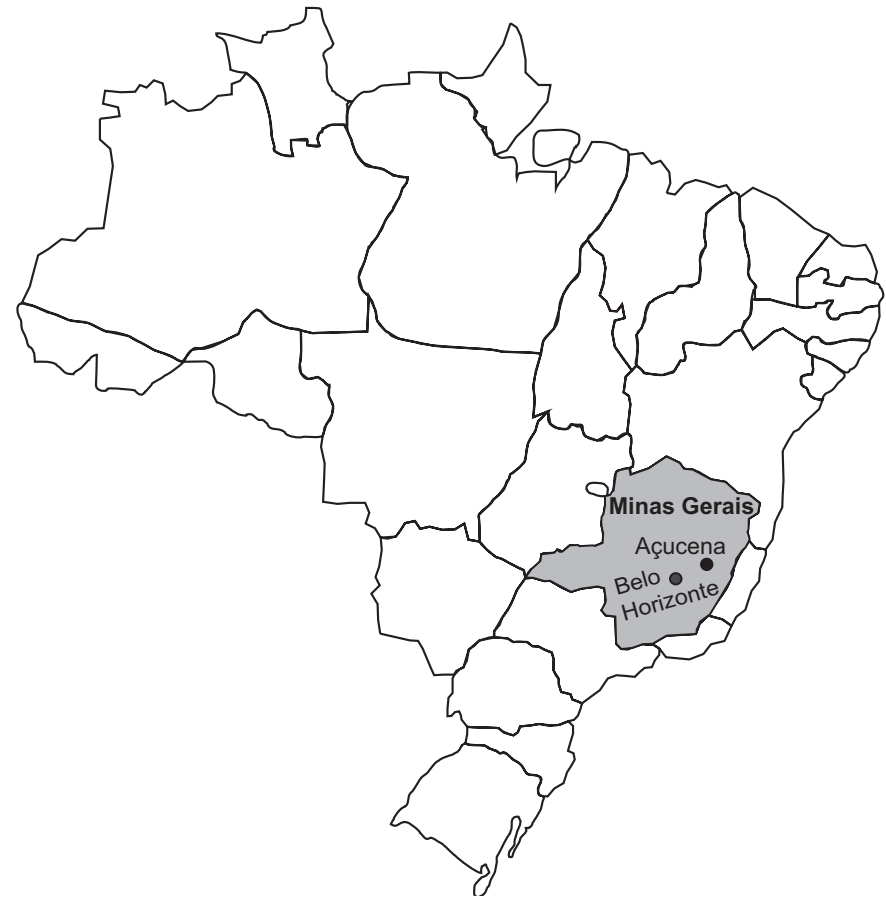

FIGURE 1 - Location of the Açucena Municipality, East region of the State of Minas Gerais, Brazil.

by school and age. Each child received a number for identification. A simple random selection was performed using the statistics program Epi Info 6.0 to calculate the final sample size. Thus, the sample size determined for this study was 603 individuals. The children were evaluated according to the recommendations of the Health Ministry ${ }^{7}$ for the laboratory diagnosis of $T$. cruzi infection or suspected Chagas disease.

During the first phase, blood samples collected on filter paper were evaluated by an ELISA test using blood eluate as in previous studies ${ }^{10}$. Next, venous blood from all participants considered positive or equivocal during the first phase was tested along with $10 \%$ of the negative samples to confirm the ELISA results. The following conventional serological tests were employed: enzyme-linked immunosorbent assay (ELISA), indirect hemaglutination assay (IHA) and indirect immunofluorescence (IIF) assay. The ELISA test was performed with serum samples diluted to 1:80, alkaline antigen of $T$. cruzi Y strain epimastigote forms and human anti-immunoglobulin $\mathrm{G}(\mathrm{IgG})$ labeled with peroxidase diluted to $1: 10,000$. The reaction was quantified by spectrometry (Bio-Rad model 680) at a wavelength of $490 \mathrm{~nm}$. Positive and negative controls were processed in parallel. The cut-off was established as the mean of the absorbance of ten negative control sera + three times the standard deviation calculated for each plate. Serum samples with absorbance values above the cut-off were considered positive.

Kits used for IHA and IIF tests were purchased from BioMérieux and Bio-Manguinhos/FIOCRUZ/RJ, respectively, and the techniques were performed according to the manufacturer's instructions. The results were considered positive when tests of at least two types were positive, uncertain when the results of 
the tests were discordant and negative when two tests were not reactive according to $\mathrm{WHO}^{9}$ and Brazilian Ministry of $\mathrm{Health}^{11}$ recommendations.

\section{Vector study and epidemiological evaluation}

The study of vectors was based on registered notifications of triatomines captured by the residents of the municipality and sent to the laboratory of the Regional Health Management (HRM) of Coronel Fabriciano during the period between 2006 and 2010. As part of the notification, several data were recorded, such as the community, place of capture and species and stage of the triatomine before examination for the presence of T. cruzi flagellates.

Subsequently, inhabitants of houses with triatomines infected with $T$. cruzi flagellates were also examined by the same serological tests, ELISA, IHA and IIF, using serum samples. The epidemiological investigation was conducted by analyzing a specific questionnaire referring to the knowledge of individuals regarding Chagas disease, its vectors, disease control and treatment and the importance of domiciliary and peridomestic conditions. The ability of the individuals to recognize the vectors was confirmed by their reactions, commentaries and ability to identify some triatomine species, eggs, nymphs and vestiges of the presence of vectors (urine + feces) as well as the association between these elements and Chagas disease transmission/infection.

\section{Ethical considerations}

This study was approved by the Ethics in Human Research Committee of the Federal University of Ouro Preto, MG, Brazil, Number 011.0.238.000-07.

\section{RESULTS}

\section{Serological screening}

After calculation of the sample size, 638 schoolchildren were selected for this study. During the first phase, ELISA tests on blood eluates revealed that $38.9 \%$ of the samples were positive, $4.7 \%$ were equivocal and $56.4 \%$ were negative.

As described in the Methods section, the 248 positive samples, the 30 equivocal samples and $10 \%$ (36) of the negative samples, for a total of 314 schoolchildren, were selected for collection of venous blood and serology for the diagnosis of T. cruzi infection. Blood was collected and examined for $92.7 \%$ (291/314) of these samples.

No schoolchildren were positive in both the ELISA and HAI tests, but 95 (95/291) were considered to have an undetermined diagnosis of $T$. cruzi infection because the results from the two tests were discordant. These 95 individuals were then examined by IIF test, and all were negative. No T. cruzi infection (Figure 2) was detected in schoolchildren of Açucena.

\section{Vector data}

From October 2006 to May 2009, 70 triatomine specimens were captured by the inhabitants of 48 dwellings in the Açucena Municipality and sent to the Regional Health Management of Coronel Fabriciano. Of these, $92.9 \%$ were $T$. vitticeps, $4.3 \%$ were

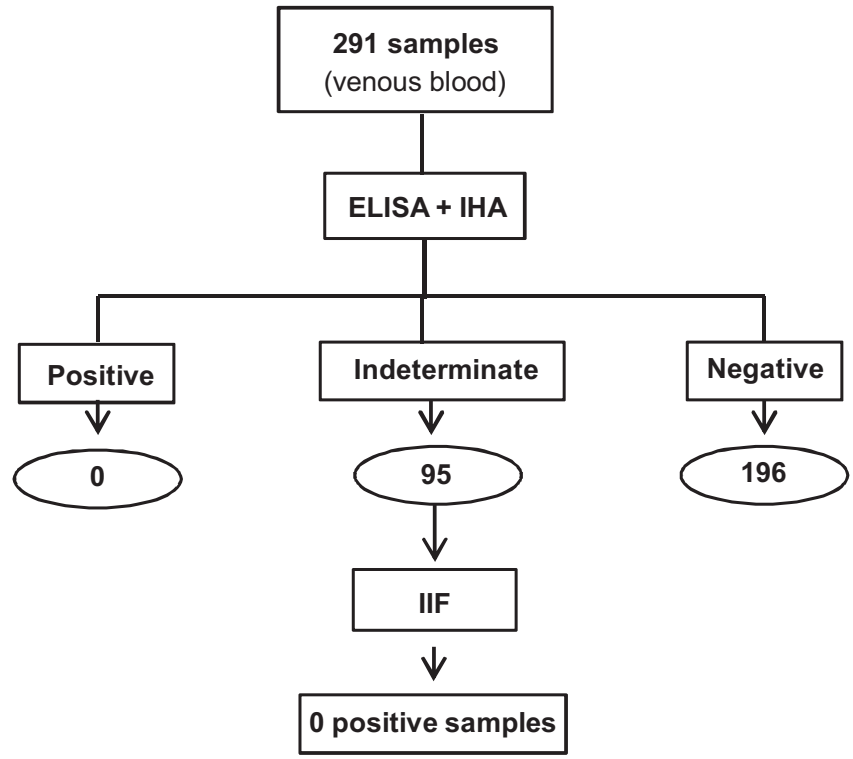

FIGURE 2 - Serological evaluation of schoolchildren in Açucena Municipality Rio Doce Valley, MG, Brazil who were reactive in the previous screening test. ELISA: enzyme-linked immunosorbent assay; IHA: indirect hemaglutination; IIF: indirect immunofluorescence.

P. diasi and $2.8 \%$ were $P$. megistus. P. vitticeps was widely spread throughout all municipalities with a higher concentration in the district of Aramirin.

Among the triatomines captured, $82.9 \%$ were intradomiciliary, and most of the triatomines were detected in the bedroom. Only 39 specimens were in a condition that was suitable for examination, and the presence of $T$. cruzi flagellates was verified in $26(66.7 \%)$ of them. All infected triatomines were of the species T. vitticeps, including two of four nymphs that were detected in one house. These infected triatomines were captured in 22 dwellings spread throughout the municipality.

When examined using the same serological tests (ELISA, IHA and IIF), none of the 51 individuals who lived in dwellings with infected triatomines was positive.

\section{Epidemiological evaluation}

The epidemiological evaluation was conducted on the inhabitants of the dwellings infested with triatomines and revealed important information regarding the residence as well as the inhabitants' knowledge of Chagas disease and its vectors (Table 1).

\section{DISCUSSION}

The decentralization of health interventions that occurred in Brazil and the intense natural environmental transformation have had important consequences for the evaluation and actions of the CDCP. The Municipality of Açucena, Rio Doce Valley studied here was located near two large industries where there was intense deforestation and planting of eucalyptus. This municipality is under the supervision of the HRM of 
TABLE 1 - Epidemiological data and knowledge of vectors and Chagas disease among the individual inhabitants of domiciliary units where infected triatomines were detected.

\begin{tabular}{lc}
\hline Domiciliary unit & Percentage (\%) \\
rural area & 96.9 \\
urban area & 3.1 \\
\hline
\end{tabular}

Characteristic of the DU

ceramic floor

90.7

brick wall

tile roof

96.6

Presence of annexes?

\begin{tabular}{lr} 
yes & 93.8 \\
no & 6.2 \\
\hline
\end{tabular}

Type of annex?

hen house

46.9

pig pen

50.0

barn

68.8

Knowledge about barbeiros

yes

93.8

no

6.2

Triatoma vitticeps

71.9

Source of information?

health agents

59.4

others

40.6

Knowledge of Chagas disease?

\begin{tabular}{lr} 
yes & 96.9 \\
no & 3.1 \\
\hline
\end{tabular}

Is Chagas disease cured after treatment?

yes

no

37.5

DU: domiciliary unit.

Coronel Fabriciano, where the ES implanted in 2001 was not maintained as recommended. Studies of the prevalence in young age groups present a significant indicator of the success of control measures for Chagas disease related to vectorial transmission ${ }^{9}$. During the first phase of the study, serological testing for T. cruzi infection in schoolchildren, no children in the selected sample was seropositive. These results confirm those of other studies in different endemic areas in Minas Gerais and reveal the benefits attributed to the CDCP implemented in vast areas of the national territory. A study that evaluated the CDCP by serological survey of 164 municipalities in Minas Gerais during the period between 1989 and $1998^{12}$ demonstrated T. cruzi infection in $15(0.04 \%)$ children aged between 7 and
14 years. The serological survey in the Municipality of Lassance in $1999^{6}$, considered the cradle of Chagas disease discovery, found no infected individuals younger than 20 years old in the study population. Two similar studies in Berilo and José Gonçalves de Minas, Jequitinhonha Valley, MG, that used similar methodologies but evaluated different samples and age groups revealed prevalences of infection of $0.17^{13}$ and $0.04 \%{ }^{10}$ when ES was first implanted in the region (1997) and after six and half years (2003), respectively. These authors attributed this low and decreasing prevalence to an effective systematic attack on vectors conducted in the region from 1982 to 1996 . Using representative samples from the population, the national investigation, which by 2005 had collected samples from 104,954 children $\leq$ five years old from all rural areas in the country with the exception of State of Rio de Janeiro, revealed 32 positive cases by ELISA and IIF ( $0.03 \%)$. Twenty children showed concomitant maternal infection, suggestive of vertical transmission, and 11 cases showed infection only in children, suggesting vectorial transmission ${ }^{14}$. These results and several other studies in distinct geographical areas of Brazil have demonstrated the virtual absence of Chagas disease transmission via the vectorial route in Brazil until 2005 ${ }^{15}$. This finding is the result of a combination of regular and systematic control programs directed at all mechanisms of Chagas disease transmission, especially vectorial and blood transfusion, alongside the important social and economic changes observed in Brazil over the last decade. However, there are no similar data available prior to 2005 for Açucena, which means that seroepidemiological studies such as the current study make important contributions to the knowledge of the present state of Chagas disease in the region.

Taking into account the absence of positive serology among the schoolchildren of Açucena and considering the presence of domestic and peridomestic triatomine species revealed by the recent actions of the HRM of Coronel Fabriciano (after 2005), this study proceeded to evaluate the vector situation in Açucena. Unfortunately, an absence of triatomine registries and other data regarding Chagas disease in the municipality was revealed. Regionally, the information was limited and recent. This situation was explained by the loss of the Health Municipal Secretary archives and at a regional level, by the transfer of health supervision for Açucena from the HRM of Teófilo Otoni to Coronel Fabriciano, which is closer to Açucena, because of the decentralization and restructuring of health interventions organized by the Health Unique System (Sistema Único de Saúde - SUS).

The need to implement a computerized, integrated registry and evaluation of the CDCP as discussed and recommended by the II Annual Meeting of Evaluation of the CDCP, Uberaba, $M G$, Brazil has been clearly demonstrated ${ }^{16}$. Although theoretical principles are decided by the SUS, the delegation of the responsibility for controlling endemics to the municipalities in 2000 caused new problems and consequences for the CDCP. In general, the municipalities do not have sufficient knowledge for controlling endemics, which makes the transfer of responsibilities and the continuous success of the programs difficult ${ }^{17,18}$. These characteristics demonstrate that similar to 
other municipalities in Brazil, Açucena has not accepted its responsibility regarding the national $\mathrm{CDCP}$. Consequently, this situation partially explains the difficulties in obtaining epidemiological and vectorial data on Chagas disease for this municipality.

From 2006 to 2009, 70 triatomines were captured by inhabitants and sent to the HRM of Coronel Fabriciano. Triatoma vitticeps was predominant followed by $P$. diasi and P. megistus. Curiously, T. sordida, the most prevalent vector species in the first study of the area, was not detected in our study, and unfortunately, no other studies were published during this interval. Moreover, the archives of data on triatomines captured in Açucena were lost as a consequence of the change of its HRM from Teófilo Otoni to Coronel Fabriciano. The insects were captured by the inhabitants mainly inside dwellings $(82.9 \%)$. Of the $55.7 \%$ of triatomines that were in a condition to be examined, $66.7 \%$ were $T$. vitticeps (including nymphs) that harbored $T$. cruzi flagellates. This triatomine species was widespread throughout the municipality, and the district with the highest concentration was Aramirim, a region with an ecosystem strongly modified by the construction of a hydroelectric dam and by the replacement of the native forest with eucalyptus plantations. These factors interfere with the insects' dispersion and change the vectorial distribution as demonstrated by other authors in different endemic regions of the country ${ }^{19-21}$.

Despite the fact that the number of $T$. vitticeps specimens detected was relatively low, the presence of nymphs was also observed. These data reveal the epidemiological importance of this species in the study region and demonstrate its potential for intradomiciliary invasion and colonization as indicated by the presence of nymphs captured in the domicile. The high rate of positivity for $T$. cruzi flagellates was similar to what has been described in other areas where this species is present. Several studies have demonstrated the high dispersion capacity of T. vitticeps, primarily in the States of Espírito Santo, Minas Gerais, Rio de Janeiro and Bahia ${ }^{22-24}$. Other authors have confirmed high rates of natural infection with $T$. cruzi, with a rate of positivity between $25 \%$ and $65 \%$ of insects examined ${ }^{24-27}$. Curiously, in the State of Espírito Santo where the frequency of $T$. vitticeps and positivity for T. cruzi is higher in rural dwellings, the prevalence of Chagas disease is low and limited to autochthonous cases of transmission by this $\operatorname{species}^{28}$. In contrast, it is well known that the domestic colonization capacity of this species is $l_{0 w}{ }^{28}$. However, these authors observed that domiciliary invasion occurred in areas of recent deforestation due to the introduction of local hydroelectric factories, and that the adults were attracted by the light of the residences. Several studies that evaluated the feeding habits of $T$. vitticeps revealed the presence of human blood in the digestive tract of the insect, demonstrating that the insects invade residences and feed on their inhabitants. These studies also showed eclectic feeding by $T$. vitticeps. The longer contact period with the host required to obtain a complete meal compared with other triatomine species of the same instar could favor the presence of multiple blood sources in $T$. vitticeps under natural conditions as has been suggested by the precipitin test ${ }^{29}$. Marsupials, rodents and birds are the most frequent food sources for this species.
This fact highlights the linkage between the wild and domestic environment and the need for the implantation of entomological and epidemiological $\mathrm{ES}^{25,26,30,31}$.

The presence of $T$. vitticeps in Açucena municipality was reported in the beginning of the 1980s during triatomine investigation activities by the CDCP. In this evaluation, the predominant triatomine species in the municipality was P. megistus, corresponding to $75 \%$ of the insects captured. This species was gradually replaced by $T$. vitticeps due to the environmental changes that occurred in vast areas of native forest when the planting of eucalyptus occurred for supplying the important and large factories of the region. Similar observations have been published by our team that verified the same replacement (P. megistus by $T$. pseudomaculata) in Berilo, Jequitinhonha Valley ${ }^{21}$, a region previously associated with higher humidity and the presence of original vegetation, as a consequence of the intense deforestation for agropecuary activities and intense planting of eucalyptus, both of which increased the aridity of the region ${ }^{32}$. This situation is common, especially in MG where agropecuary is present with several siderurgic industries in vast areas as discussed in the study by Forattini ${ }^{17}$.

In light of the high rates of positivity for $T$. cruzi observed in T. vitticeps captured in dwellings, it was important to evaluate the inhabitants of the dwellings where these insects were captured. Serology and evaluation of several epidemiological features of the disease were performed. The serological results revealed an absence of infection in all residents examined, correlating with the absence of Chagas disease in the schoolchildren and indicating that vectorial transmission is not present in Açucena. However, it is not possible to ensure that transmission is not occurring, only that it is apparently much less frequent than before. This fact by itself illustrates the importance of maintaining ES because $T$. vitticeps is infected, enters homes and can feed on human blood. Therefore, transmission can potentially occur at any time.

The responses to the questionnaire presented to the study participants revealed that the infested dwellings were spread throughout the rural zone of the municipality and were of a good standard of construction. The existence of annexes, mainly with chickens, was common and close to the houses. The majority of the inhabitants of infested dwellings recognized triatomines and had a general knowledge of Chagas disease. This information explains the fact that Açucena is the municipality responsible for the majority of the notifications registered at the HRM of Coronel Fabriciano.

According to one study that evaluated the $\mathrm{ES}^{14}$, the importance of popular participation through formal representatives (Municipal Council of Health and health and education professionals) and natural leaders of the community where each participates in the decisions and in the planning of activities was recognized. This strategy is designed by the SUS to stimulate popular participation in all aspects related to health, particularly prophylaxis or prevention. Data from Açucena concerning knowledge among the population about the vectors of Chagas disease and the disease itself shows that people are 
informed and able to play a role in ES. In the municipality, the ES for Chagas disease was performed concomitantly with other control programs (dengue, rabies, leishmaniasis and others), and there are no specific and previously planned actions directed exclusively against Chagas disease in Açucena. ES is limited to visits to the residences by health agents and when requested by inhabitants forwarding triatomines for examination. Due to the absence of a consolidated policy for ES for Chagas disease in Açucena, dwellings where triatomines are captured are not being inspected for the presence of colonies nor receiving the chemical treatment recommended. Therefore, it is clear that the CDCP omits a primary implementation step, the attack on the domesticated vector, potentially allowing the introduction of triatomines into human residences with consequent exposure of their inhabitants to T. cruzi infection. In fact, no association was detected between triatomine infestation and human infection even when the invading triatomines exhibited high rates of T. cruzi infection. This finding illustrates a new situation that fundamentally differs from the classic and historical patterns of intradomiciliary infestation by species of triatomines with a high capacity for colonizing artificial environments. Apparently, in the present condition described for $T$. vitticeps, active research on triatomines and selective spraying of insecticides do not seem to be suitable methods for preventing transmission of T. cruzi to humans. However, public health agencies still have a responsibility to prevent the installation of new foci of domiciliary transmission of infection. Given this situation, attention to the notification of triatomines in dwellings is the most suitable method and needs to be maintained as a priority under these conditions.

Several studies indicate that for the ES of Chagas disease to be suitable for controlling transmission in areas with a low density of triatomines, its permanency and the participation of the State through collaboration with all governmental levels, including the local population, are required ${ }^{12,18,33}$. The absence of a registry of Chagas disease in Açucena as well as the discontinuity of the CDCP in this municipality after 1996 and the presence of triatomines captured in dwellings demonstrates the need to reinforce the system of ES for Chagas disease to sustain vectorial control and to better understand the adaptation of the new triatomine species and the risk for Chagas disease transmission.

Finally, the authors would like to highlight the great difficulty in conducting this research as well as in maintaining the CDCP. The former is due to the small number of research workers and research centers pursuing this type of work, and the latter is due the absence of historical registers and the poor community participation. Thus, endemic diseases such as Chagas disease can become neglected, characterized by a great disparity between intentions and actions.

\section{ACKNOWLEDGMENTS}

We would like to thank the local facilities of Açucena Municipality and Global Science Editing Ltd for their assistance in editing this manuscript.

\section{CONFLICT OF INTEREST}

The authors declare that there is no conflict of interest.

\section{FINANCIAL SUPPORT}

This study was funded by grants from Pró-reitoria de Extensão (PROEX), Universidade Federal de Ouro Preto and Fundação de Amparo à Pesquisa do Estado de Minas Gerais (FAPEMIG).

\section{REFERENCES}

1. World Health Organization (WHO). Reporter del grupo de trabajo científico sobre La enfermedad de Chagas, 2005. 17 - 20 de abril de 2005, Buenos Aires, Argentina. [Cited 2007 July]. Available at: www.who.int/tdr/.

2. World Health Organization. La enfermedad de Chagas (tripanosomiasis americana). Nota descriptiva $\mathrm{n}^{\circ} 340$. Mayo de 2010. [Cited 2011 January 21]. Available at: http://www.who.int/mediacentre/factsheets/fs340/es/.

3. Lent H, Wygodzinsky P. Revision of the Triatominae (Hemiptera, Reduviidae), and their significance as vectors of Chagas disease. Bull Am Mus Nat History 1979; 163:127-520.

4. Silveira AC. Situação do controle da transmissão vetorial da doença de Chagas nas Américas. Cad Saude Publica 2000; 16 (suppl II):35-42.

5. Villela MM, Souza JB, Mello VP, Azeredo BVM, Dias JCP. Vigilância entomológica da doença de Chagas na região centro-oeste de Minas Gerais, Brasil, entre os anos de 2000 e 2003. Cad Saude Publica 2005; 21:878-886.

6. Dias JCP, Machado EMM, Borges EC, Moreira EF, Gontijo C, Azeredo BVM. Doença de Chagas em Lassance, MG. Reavaliação clínico-epidemiológica 90 anos após a descoberta de Carlos Chagas. Rev Soc Bras Med Trop 2002; 35:167-176

7. Dias JCP, Loyola CCP, Brener S. Doença de Chagas em Minas Gerais: Situação Atual e Prespectivas. Rev Brasil Malariol Doenças Trop 1985; 37:7-28.

8. Dias JCP. Vigilância epidemiológica em doença de Chagas. Cad Saude Publica 2000; 16 (suppl II):43-59.

9. Ministério da Saúde. Inquérito sorológico para avaliação do programa de Controle da Doença de Chagas. Fundação Nacional de Saúde. Departamento de Operações. Coordenação de Controle de Doenças Transmitidas por Vetores. $1^{\text {a }}$ ed. Brasília: Ministério de Saúde; 1994.

10. Borges JD, Assis MGF, Gomes LV, Dias JCP, Pinto IDM, Martins-Filho AO, et al. Seroprevalence of Chagas disease in schoolchildren from two municipalities of Jequitinhonha Valley, Minas Gerais; six years following the onset of epidemiological surveillance. Rev Inst Med Trop São Paulo 2006; 48:81-86.

11. World Health Organization. Control of Chagas Disease. WHO Techn Rep Sers 1991; 811:2-11.

12. Moreno EC, Baracho L. Vigilância epidemiológica no Programa de Controle da Doença de Chagas em Minas Gerais, Brasil (1984-1998). Cad Saude Publica 2000; 16 (suppl II):113-116.

13. Montoya R, Dias JCP, Coura JR. Chagas diseases in a community in southeast Brasil. I. A serologic follow-up study on a vector controlled area. Rev Inst Med Trop São Paulo 2003; 45:269-274.

14. Luquetti AO, Passos ADC, Silveira AC, Ferreira AW, Macedo V, Prata AR. The National Survey of seroprevalence for evaluation of the control of Chagas disease in Brazil (2001-2008). Rev Soc Bras Med Trop 2011; 44 (suppl II): 108-121.

15. Sessa PA, Pimentel RR, Ferreira AL, Falqueto A. Soroprevalência da doença de Chagas em crianças em idade escolar do Estado do Espírito Santo, Brasil, em 1999-2000. Cad Saude Publica 2002; 18:1765-1769. 
16. Secretaria de Vigilância em Saúde. Boletim Epidemiológico Eletrônico: Controle da Doença de Chagas. Ano 03, n. ${ }^{\circ}$ 04. [Cited 2003 December 10]. Available at: www.saude.gov.br/svs/.

17. Schmunis GA, Dias JCP. La reforma del sector salud, descentralización, prevención y control de enfermedades transmitidas por vectores. Cad Saude Publica 2000; 16 (suppl II):117-123.

18. Villela MM, Souza JMB, Melo VP, Dias JCP. Vigilância Epidemiológica da doença de Chagas em programa descentralizado: avaliação de conhecimentos e práticas de agentes municipais em região endêmica de Minas Gerais, Brasil. Cad Saude Publica 2007; 23:2428-2438.

19. Forattini OP. Biogeografia, origem e distribuição da domiciliação de triatomíneos domiciliares na região central do Brasil. Rev Saude Publica 1980; 13:265-299.

20. Carcavallo RU, Curto de Casas SI, Sherlock IA, Galíndez-Girón I, Jurberg J, Galvão C, et al. Geographical distribution and altilatitudinal dispersion. In: Carcavallo RU, Galindz-Girón I, Jurberg J, Lent H, editors. Atlas of Chagas Disease Vectors in the Americas. Vol. III. Rio de Janeiro: FIOCRUZ; 1999. p. 747-792.

21. Machado-de-Assis GF, Azeredo BVM, Fuente ALC, Diotaiuti L, Lana M. Domiciliation of Triatoma pseudomaculata (Corrêa e Espínola 1964) in the Jequitinhonha Valley, State of Minas Gerais. Rev Soc Bras Med Trop 2007; 40:391-396.

22. Carneiro M, Loiola CCP, Lima SG, Diotauiti L. Presença do Triatoma vitticeps em ecótopos artificiais no Estado de Minas Gerais. XII Reunião Anual sobre Pesquisa Básica em Doença de Chagas, Caxambu: VE-40; 1985.

23. Galvão C, Carcavallo R, Rocha DS, Jubert J. A checklist of the currente valid species of the subfamily Triatominae Jeannel, 1919 (Hemiptera, Reduviidae) and their geografical distribution, with nomenclatural and taxonomic notes. Zootaxa 2013; 202:1-36.

24. Souza RCM, Barbosa SE, Sonoda IV, Azeredo BVM, Romanha AJ, Diotaiuti L. Population dynamics of Triatoma vitticeps (Stål, 1859) in Itanhomi, Minas Gerais, Brazil. Mem Inst Oswaldo Cruz 2008; 103:14-20.

25. Dias JCP, Feitosa VR, Ferraz Filho AN, Rodrigues VLC, Alencar AS, Sessa PA. Fonte alimentar e potencial vetorial de Triatoma vitticeps
(Stal, 1859) com relação à doença de Chagas humana no estado do Espírito Santo, Brasil (Hemiptera, Reduvidae). Mem Inst Oswaldo Cruz 1989; 84 (suppl IV):165-173.

26. Lorosa ES, Valente MVMP, Cunha V, Lent H, Jurberg J. Foco de doença de Chagas em Arcádia, Estado do Rio de Janeiro, Brasil. Mem Inst Oswaldo Cruz 2003; 98:885-887.

27. Santos CB, Leite GR, Ferreira GEM, Ferreira AL. Infecção natural de Triatoma vitticeps (Stal, 1859) por flagelados morfologicamente semelhantes a Trypanossoma cruzi (Chagas, 1909) no estado do Espírito Santo. Rev Soc Bras Med Trop 2006; 39:89-98.

28. Santos CB, Ferreira AL, Leite GR, Ferreira GEM, Rodrigues AAF, Falqueto A. Peridomiciliary colonies of Triatoma vitticeps (Stal, 1859) (Hemiptera, Reduviidae, Triatominae) infected with Trypanosoma cruzi in rural areas of the state of Espírito Santo, Brazil. Mem Inst Oswaldo Cruz 2005; 100:471-473.

29. Souza RCM, Soares A, Alves CL, Lorosa ES, Pereira MH, Diotaiuti L. Feeding behavior of Triatoma vitticeps (Reduviidae: Triatominae) in the state of Minas Gerais, Brazil. Mem Inst Oswaldo Cruz 2011; 106 : $16-22$.

30. Gonçalves TCM, Oliveira E, Dias LS, Almeida MD, Nogueira WO, Pires FDA. An investigation on the ecology of Triatoma vitticeps (Stal, 1859) and its possible role in the transmission of Trypanosoma cruzi, in the locality of Triunfo, Santa Maria Madalena municipal district, state of Rio de Janeiro, Brazil. Mem Inst Oswaldo Cruz 1998; 93:711-717.

31. Gonçalves TC, Rocha DS, Cunha RA. Feeding patterns of Triatoma vitticeps in the state of Rio de Janeiro, Brazil. Rev Saude Publica 2000; 34: 348-352.

32. Assis GF, Azeredo BV, Gorla D, Diotaiuti L, Lana M. Entomological surveillance of Chagas disease in Berilo municipality, Jequitinhonha Valley, State of Minas Gerais, Brazil. Rev Soc Bras Med Trop 2009; 42:615-621.

33. Ministério da Saúde. Superintendência de Campanhas de Saúde Pública. Manual de Normas Técnicas da Campanha da Doença de Chagas. Brasília, DF: Centro de Documentação do Ministério da Saúde; 1980. 